\title{
STATUSRESISTENSI VEKTOR DEMAM BERDARAH DENGUE (Aedes aegypti) TERHADAP INSEKTISIDA JENIS FENITROTHION $1 \%$ DI KABUPATEN KUDUS PROVINSI JAWA TENGAHTAHUN 2017
}

\author{
Rahmayanti Amini $^{*}$, Aris Santjaka ${ }^{* *}$, Yohanes Didik Setiawan ${ }^{* * *}$ ) \\ Jurusan Kesehatan Lingkungan, Politeknik Kesehatan Kemenkes Semarang, \\ Jl.Raya Baturaden KM 12 Purwokerto, Indonesia
}

\begin{abstract}
Abstrak
Penyakit Demam Berdarah Dengue (DBD) merupakan penyakit akut akibat infeksi virus dengue yang ditularkan melalui gigitan nyamuk Aedes aegypti betina.Kasus DBD di Kabupaten Kudus tahun 20122016 setiap tahunnya meningkat.Pengendalian vektor nyamuk Aedes aegypti secara kimia dengan menggunakan insektisida.Insektisida yang digunakan secara terus-menerus dapat menyebabkan nyamuk menjadi resisten.Penelitian ini bertujuan untuk mengetahui status resistensi nyamuk Aedes aegypti terhadap insektisida Fenitrothion 1\% di Kabupaten Kudus Tahun 2017.Jenis penelitian ini termasuk penelitian deskriptif yang bertujuan untuk mengetahui dan menggambarkan kategori resistensi nyamuk Aedes aegypti terhadap insektisida Fenitrothion 1\% di Kabupaten Kudus Tahun 2017.Hasil uji resistensi menggunakan metode susceptibility test dengan impregnated paper Fenitrothion 1\% yaitu kematian nyamuk uji dari Kecamatan Kaliwungu, Kecamatan Kota Kudus, dan Kecamatan Jati menunjukkan persentase kematian sebanyak 100\%, sedangkan untuk Kecamatan Mejobo menunjukkan persentase kematian nyamuk uji sebesar 98,67\%.Kesimpulan penelitian yaitu nyamuk Aedes aegypti di Kabupaten Kudus dinyatakan rentan/sensitif terhadap insektisida Fenitrothion 1\% karena kematian nyamuk uji $>98 \%$. Disarankan Dinas Kesehatan Kabupaten Kudus menggunakan insektisida Fenitrothion 1\% sebagai alternative cara pengendalian nyamuk Aedes aegypti secara kimia, melakukan pemantauan uji resistensi kembali terhadap insektisida yang digunakan dalam pemberantasan vektor DBD, dan melakukan rotasi atau pergantian jenis insektisida yang digunakan dalam pengendalian nyamuk Aedes aegypti secara kimia.
\end{abstract}

Kata kunci:insektisida; resistensi; nyamuk Aedes aegypti; kesehatan lingkungan

\begin{abstract}
[Resistance Status of Dengue Hemorrhagic Fever's Vektor (Aedes aegypti) on Insecticide Types of Fenitrothion 1\% in Kudus Regency Central Java Province Year of 2017] Dengue Hemmorhaghic Fever(DHF) is an acute disease caused by dengue virus infection that is transmitted through a female Aedes aegypti mosquito bite.The case of DHF in Kudus Regency in 2012-2016 increases annually.Control of Aedes aegypti mosquito vectors chemically by using insecticides. Insecticides used continuously can cause mosquitoes to become resistant. This study aims to determine the status of Aedes aegypti mosquito resistance against 1\% Fenitrothion insecticide in Kudus Regency in 2017. This type of research includes descriptive research that aims to find out and describe the Aedes aegypti mosquito resistance category against 1\% Fenitrothion insecticide in Kudus Regency 2017. The result of resistance test using susceptibility test method with impregnated paper Fenitrothion 1\% ie death of mosquito test from Kaliwungu subdistrict, Kota Kudus and Jati subdistrict shows 100\% death percentage, while for Mejobo District showed the percentage of death of mosquito test 98,67\%. The research conclusion that Aedes aegypti mosquito in Kudus District is considered vulnerable / sensitive to insecticide Fenitrothion 1\% due to death of mosquito test> 98\%. It is suggested that the District Health Office of Kudus Regency uses 1\% Fenitrothion insecticide as an alternative way of controlling Aedes aegypti mosquitoes chemically, monitoring the resistance test back against insecticides used in the eradication of DHF vector, and rotating or changing the type of insecticide used in Aedes aegypti mosquito control chemically.
\end{abstract}

Keywords: insecticide; resistance; Aedes aegypti mosquitoes; environmental health

\section{Pendahuluan}

Perbaikan kesehatan rakyat dilakukan melalui upaya peningkatan, pencegahan, penyembuhan, dan pemulihan dengan mendekatkan dan memeratakan pelayanan kesehatan kepada rakyat.Pembangunan kesehatan ditujukan kepada peningkatan pemberantasan 
penyakit menular dan penyakit rakyat, serta penyuluhan kesehatan masyarakat untuk memasyarakatkan perilaku hidup sehat yang dimulai sedini mungkin.Salah satu bidang dari upaya kesehatan adalah pemberantasan penyakit menular dan penyakit rakyat (UU RI, 1984, h.7).Jenis-jenis penyakit menular yang dapat menimbulkan wabah adalah Kolera, Pes, Demam Berdarah Dengue, dan lain-lain (Permenkes RI, 2010, h.5).

Undang-undang Republik Indonesia Nomor 36 Tahun 2009 tentang Kesehatan menyebutkan bahwa upaya kesehatan lingkungan ditujukan untuk mewujudkan kualitas lingkungan yang sehat, baik fisik, kimia, biologi, maupun sosial yang memungkinkan setiap orang mencapai derajat kesehatan yang setinggitingginya. Salah satu upaya dalam hal meningkatkan kualitas kesehatan lingkungan yaitu dengan cara menekan dan mengendalikan penyakit Demam Berdarah Dengue.

Penyakit Demam Berdarah Dengue (DBD) pertama kali dilaporkan pada tahun 1968 di Jakarta dan Surabaya. Pada tahun 2010 penyakit DBD telah tersebar di 33 provinsi, 440 kabupaten/kota. Sejak ditemukan pertama kali kasus DBD meningkat terus bahkan sejak tahun 2004 kasus meningkat sangat tajam. Kenaikan kasus DBD berbanding terbalik dengan angka kematian (CFR) akibat DBD, dimana pada awal dilaporkan di Surabaya dan Jakarta angka kematian (CFR) DBD berkisar 41,3\% kemudian menunjukan penurunan pada tahun 2012 telah mencapai 0,90\% (Kemenkes RI, 2013, h.8).

Penyakit Demam Berdarah Dengue di Provinsi Jawa Tengah masih menjadi masalah prioritas, hal ini terbukti bahwa dari 35 kabupaten/kota di Jawa Tengah seluruhnya terdapat kasus Demam Berdarah Dengue. Dinas Kesehatan Provinsi JawaTengah melaporkan bahwa penyakit DBD masih tetap menjadi ancaman dengan tingkat kematian (Case Fatality Rate/CFR) lebih tinggi dari rata-rata nasional yaitu CFR DBD di Jawa Tengah sebesar 1,58\% dengan Standar Nasional yaitu $<1 \%$ dan untuk angka kesakitan (Incidence Rate/IR) DBD Jawa Tengah yaitu 15,81/100.000 penduduk dengan Target Nasional 51/100.000 penduduk. Angka kesakitan (IR) dan angka kematian (CFR) Demam Berdarah Dengue di Provinsi Jawa Tengah pada tahun 2012 sebesar (IR19,29/100.000 penduduk dan CFR1,52\%), tahun 2013 sebesar (IR45,52/100.000 penduduk dan CFR1,21\%), tahun 2014 sebesar (IR32,95/100.000 penduduk dan CFR1,44\%), tahun 2015 sebesar (IR 47,9/100.000 penduduk dan CFR 1,56\%), dan pada Bulan Januari-

\footnotetext{
${ }^{*}$ E-mail:amini.rahmayanti@gmail.com

${ }^{* *}$ E-mail:arissantjaka@gmail.com

${ }^{* * *)}$ E-mail : didikset44@yahoo.co.id
}

Juni2016sebesar (IR15,81/100.000 penduduk dan CFR 1,58\%). Pada Bulan Januari-Juni tahun 2016 angka kesakitan tertinggi di Kota Surakarta yaitu 57,17/100.000 penduduk dan terendah di Wonogiri sebesar 1,58/100.000 penduduk, sedangkan angka kematian tertinggi di Kudus yaitu 5,36\%(Dinas Kesehatan Provinsi Jawa Tengah, 2016).

Kabupaten Kudus berdasarkan laporan kesehatan Dinas Kesehatan Kabupaten (DKK) Kudus tahun 2015 tercatat sebanyak 606 kasus DBD atau meningkat dibanding tahun sebelumnya yaitu 439 kasus. Dinas Kesehatan Provinsi Jawa Tengah Tahun 2016 menyatakan bahwa Kabupaten Kudus merupakan daerah endemis Demam Berdarah Dengue (DBD) dengan angka kesakitan (Incidence Rate/IR) pada bulan Januari-Juni 2016 yaitu 31,02/100.000 penduduk dan angka kematian (Case Fatality Rate/CFR) tertinggi di Jawa Tengah yaitu 5,36\%.

Pengendalian vektor dewasa dengan cara fogging masih menjadi pilihan utama dalam penanggulangan DBD. Tujuan kegiatan ini untuk membunuh nyamuk Aedes aegypti dewasa agar terputus mekanisme penularan penyakit DBD.Selain itu, masyarakat rumah tangga juga biasa melakukan upaya pembunuhan nyamuk Aedes aegypti menggunakan insektisida rumah tangga. Upaya tersebut akan efektif jika nyamuk yang menjadi sasaran belum resisten terhadap insektisida yang dipakai. Akan tetapi, penggunaan insektisida dalam jangka waktu panjang dengan frekuensi tinggi untuk pengendalian serangga menyebabkan peningkatan resistensi nyamuk terhadap senyawa aktif yang terkandung di dalamnya (Lidia dan Widianingrum, 2008).Data resistensi nyamuk Aedes aegypti sangat diperlukan sebagai bahan pertimbangan dalam kegiatan pelaksanaan pengendalian DBD, khususnya pengendalian secara kimia.Hal tersebut sangatlah penting untuk selalu memonitor derajat kerentanan nyamuk Aedes aegypti terhadap insektisida tertentu yang digunakan selama kegiatan pengendalian DBD.Penentuan status kerentanan nyamuk Aedes aegypti secara berkala sangat diperlukan untuk mendapatkan data dasar deteksi lebih lanjut dan monitoring terjadinya resistensi.Dengan demikian karakteristik potensial terjadinya resistensi dapat diketahui lebih awal untuk bahan pertimbangan dalam strategi pengendalian vektor nyamuk Aedes aegypti dewasa.

Penelitian yang dilakukan oleh Irawan Endy Pratama di Desa Sidamulih Kecamatan Rawalo Kabupaten Banyumas pada Tahun 2016 dengan indikator densitas nyamuk 3 hari sesudah fogging focus kedua justru lebih tinggi dari sebelum di-fogging, sedangkan 3 hari sesudah fogging focus pertama meskipun densitas nyamuk turun, tetapi secara statistik tidak signifikan artinya 3 hari sesudah fogging focus pertama dengan sebelum di-fogging focus densitasnya 
sama. Hal tersebut menunjukan indikasi adanya resistensi nyamuk Aedes aegypti terhadap insektisida tertentu.

Indikasi resistensi nyamuk Aedes aegypti terhadap berbagai jenis insektisida di Indonesia sudah terdeteksi pada beberapa penelitian, seperti dalam penelitian Widiarti et al. pada Tahun 2011 di Provinsi Jawa Tengah dan Daerah Istimewa Yogyakarta, hasil uji susceptibility untuk mengetahui kerentanan nyamuk terhadap insektisida menggunakan impregnated paper standar WHO, hasilnya vektor Demam Berdarah Dengue (DBD) Aedes aegypti di Jawa Tengah dan Daerah Istimewa Yogyakarta telah resisten terhadap insektisida Malathion 0,8\%, Bendiokarb 0,1\%, Lambdasihalotrin 0,05\%, Permetrin 0,75\%, Deltametrin 0,05\%, dan Etofenprok 0,5\%, akan tetapi masih peka/susceptible terhadap insektisida Sipermetrin 0,05\%. Penelitian yang dilakukan oleh Yohanes Didik Setiawan (2016) di Kabupaten Jepara Provinsi Jawa Tengah telah resisten terhadap insektisida Malathion 0,8\%, Sipermetrin 0,05\%, Permetrin 0,75\%, Propoxur $0,1 \%$, toleran terhadap insektisida Lambda-sihalotrin 0,05\%, Deltametrin 0,05\%, Bendiocarb 0,1\%, dan masih sensitif terhadap insektisida Fenitrothion 1\%.

Resistensi bersifat generatif dan merupakan rintangan dalam keberhasilan pengendalian vektor secara kimia.Deteksi dini resistensi vektor terhadap insektisida dapat bermanfaat sebagai evaluasi untuk pemilihan insektisida yang tepat dalam pengendalian vektor secara kimia.Kewaspadaan terhadap kemungkinan terjadinya resistensi insektisida yang digunakan serta membantu kebijakan program merotasi, mengganti, dan mencari insektisida yang tepat untuk pengendalian kimia vektor DBD.

Tujuan penelitian ini adalah Mengetahui status resistensi vektor Demam Berdarah Dengue (Aedes aegypti) terhadap insektisida Fenitrothion $1 \%$ di Kabupaten Kudus.

\section{Bahan dan Metode}

Penelitian ini termasukdeskriptif yang bertujuan untuk mengetahui dan menggambarkan status resistensi nyamuk Aedes aegypti terhadap insektisida Fenitrothion 1\% di Kabupaten Kudus Provinsi Jawa Tengah Tahun 2017.

Lokasi pengambilan larva Aedesaegypti dilaksanakan di Kabupaten Kudus Provinsi Jawa Tengah dengan diwakili oleh empat kecamatan yang terdiri dari dua kecamatan high endemis DBD, satu kecamatan sporadis, dan satu kecamatan low endemis. Setiap kecamatan akan diwakili oleh dua kelurahan/desa dan diambil larva pada 50 rumah setiap kelurahan/desa.

Kegiatan uji resistensi nyamuk Aedes aegypti terhadap insektisida Fenitrothion 1\% dilakukan di Laboratorium Entomologi Balai Besar Teknik
Kesehatan Lingkungan dan Pengendalian Penyakit (BBTKLPP) Yogyakarta.

\section{Hasil dan Pembahasan}

a. Gambaran Umum

1) Keadaan Geografi

KabupatenKudus berada pada ketinggian ratarata \pm 55 meter di atas permukaan laut. Nyamuk Aedes aegypti tersebar luas di daerah tropis dan sub tropis, nyamuk ini dapat hidup dan berkembang biak sampai ketinggian daerah \pm 1.000 meter di atas permukaan air laut. Di atas ketinggian +1.000 meter dari permukaan air laut nyamuk ini tidak dapat berkembang biak, karena pada ketinggan tersebut suhu udara terlalu rendah, sehingga tidak memungkinkan bagi kehidupan nyamuk tersebut (Depkes RI, 2005). Nyamuk Aedes aegypti yang berada Kabupaten Kudus dapat tumbuh dan berkembang biak dengan baik mengingat lokasi Kabupaten Kudus berada pada ketinggian rata-rata \pm 55 meter di atas permukaan laut (kurang dari 1.000 meter dari permukaan air laut).

2) Laboratorium BBTKLPP Yogyakarta

Pemeriksaan uji resistensi nyamuk Aedes aegypti yang berasal dari Kabupaten Kudus dengan metode susceptibility test menggunakan impragnated paper Fenitrothion 1\% dilaksanakan di Laboratorium Entomologi BBTKLPP Yogyakarta yang beralamat di Jalan Wiyoro Lor No. 21 Baturetno, Banguntapan, Bantul, Yogyakarta. Laboratorium Entomologi dengan ruang kerja seluas $\pm 30 \mathrm{~m}^{2}$ dilengkapi dengan fasilitas alat dan bahan guna menunjang kebutuhan pengujian. Sampel nyamuk Aedes aegypti yang dibutuhkan dalam penelitian dikembangbiakkan di Laboratorium Entomologi.

b. Gambaran Khusus

1) Data Kasus Demam Berdarah Dengue (DBD)

Kasus DBD di Kabupaten Kudus berdasarkan laporan kesehatan Dinas Kesehatan Kabupaten (DKK) Kudus Tahun 2016 tercatat sebanyak 776 kasus atau meningkat dibanding tahun sebelumnya yaitu pada Tahun 2015 sebanyak 606 kasus, Tahun 2014 sebanyak 439 kasus, Tahun 2013 sebanyak 501 kasus, dan Tahun 2012 sebanyak 162 kasus. Dinas Kesehatan Provinsi Jawa Tengah Tahun 2016 menyatakan bahwa Kabupaten Kudus merupakan daerah endemis Demam Berdarah Dengue (DBD) dengan angka kesakitan (Incidence Rate/IR) pada Bulan Januari-Juni 2016 yaitu 31,02/100.000 penduduk dan angka kematian (Case Fatality Rate/CFR) tertinggi di Jawa Tengah yaitu 5,36\%.

Penanggulangan pemutusan rantai penularan kasus Demam Berdarah Dengue (DBD) di Kabupaten Kudus dilakukan dengan cara pengasapan (fogging). Program fogging di Kabupaten Kudus mengalami kenaikan dari Tahun 2013 yang dilakukan sebanyak 120 kali fogging, Tahun 2014 dilakukan 135 kali fogging, 
Tahun 2015 dilakukan sebanyak 210 kali fogging, dan pada Tahun 2016 dilakukan fogging sebanyak 270 kali. 2) Hasil Penangkapan Larva

Pengambilan larva nyamuk dilakukan dari tempat penampungan air (TPA) di dalam rumah atau di dekat rumah dengan sasaran larva nyamuk Aedesaegypti. Jenis tempat perindukan buatan secara berurutan dari yang terbanyak yaitu bak mandi sejumlah 340 (63,43\%), ember sejumlah 40 (7,46\%), gentong sejumlah 27 (5,04\%), dan dispenser sebanyak 17 (3,17\%).

3) Hasil Uji Resistensi

Tabel 1 Hasil Uji Resistensi Kecamatan Kaliwungu (Puskesmas Kaliwungu)

\begin{tabular}{|c|c|c|c|c|}
\hline \multirow[b]{2}{*}{ No. } & \multirow[b]{2}{*}{ Ulangan } & \multicolumn{2}{|c|}{ Nyamuk Uji } & \multirow[b]{2}{*}{$\begin{array}{l}\text { \% Kematian } \\
\text { Nyamuk Uji }\end{array}$} \\
\hline & & $\sum_{\substack{\text { Nyamuk } \\
\text { Uji }}}$ & $\sum_{\substack{\text { Nyamuk } \\
\text { Mati }}}$ & \\
\hline 1 & Ulangan I & 25 & 25 & $100 \%$ \\
\hline 2 & Ulangan II & 20 & 20 & $100 \%$ \\
\hline 3 & Ulangan III & 25 & 25 & $100 \%$ \\
\hline \multicolumn{4}{|c|}{ Rata-rata } & $100 \%$ \\
\hline
\end{tabular}

Jumlah kematian nyamuk uji dengan pengujian metode susceptibility test mengunakan impragnated paper Fenitrothion 1\% di Kecamatan Kaliwungu Kabupaten Kudus Tahun 2017 menunjukan bahwa kematian nyamuk uji pada pengulangan I, II, dan III sebanyak $100 \%$ ditunjukkan pada Tabel 1.

Tabel 2Hasil Uji Resistensi Kecamatan Kota Kudus (Puskesmas Purwosari)

\begin{tabular}{ccccc}
\hline & & \multicolumn{3}{c}{ Nyamuk Uji } \\
\cline { 3 - 4 } No. & Ulangan & $\sum$ & $\sum$ & \% Kematian \\
& & Nyamuk & Nyamuk \\
& & Uji & Mati & \\
\hline 1 & Ulangan I & 25 & 25 & $100 \%$ \\
2 & Ulangan II & 25 & 25 & $100 \%$ \\
3 & Ulangan III & 25 & 25 & $100 \%$ \\
\hline \multicolumn{5}{c}{ Rata-rata } \\
\hline
\end{tabular}

Jumlah kematian nyamuk uji dengan pengujian metode susceptibility test mengunakan impragnated paper Fenitrothion 1\% di Kecamatan Kota Kudus Kabupaten Kudus Tahun 2017 menunjukan bahwa kematian nyamuk uji pada pengulangan I, II, dan III sebanyak $100 \%$ ditunjukkan pada Tabel 2.

Tabel 3 Hasil Uji Resistensi Kecamatan Jati (Puskesmas Ngembal Kulon)

\begin{tabular}{ccccc}
\hline & & \multicolumn{3}{c}{ Nyamuk Uji } \\
\cline { 3 - 4 } No. & Ulangan & $\sum$ & $\sum$ & \% Kematian \\
& & Nyamuk & Nyamuk & Nyamuk Uji \\
& & Uji & Mati & \\
\hline 1 & Ulangan I & 25 & 25 & $100 \%$ \\
2 & Ulangan II & 25 & 25 & $100 \%$ \\
3 & Ulangan III & 25 & 25 & $100 \%$ \\
\hline \multicolumn{5}{c}{ Rata-rata } \\
\hline
\end{tabular}

Jumlah kematian nyamuk uji dengan pengujian metode susceptibility test mengunakan impragnated paper Fenitrothion 1\% di Kecamatan Jati Kabupaten Kudus Tahun 2017 menunjukan bahwa kematian nyamuk uji pada pengulangan I, II, dan III sebanyak 100 $\%$ ditunjukkan pada Tabel 3.

Tabel 4 Hasil Uji Resistensi Kecamatan Mejobo (Puskesmas Jepang)

\begin{tabular}{ccccc}
\hline & & \multicolumn{3}{c}{ Nyamuk Uji } \\
\cline { 3 - 5 } No. & Ulangan & $\sum$ & $\sum$ & \% Kematian \\
& & Nyamuk & Nyamuk & Nyamuk Uji \\
& & Uji & Mati & \\
\hline 1 & Ulangan I & 25 & 24 & $96 \%$ \\
2 & Ulangan II & 20 & 20 & $100 \%$ \\
3 & Ulangan III & 20 & 20 & $100 \%$ \\
\hline \multicolumn{5}{c}{ Rata-rata } \\
\hline
\end{tabular}

Jumlah kematian nyamuk uji dengan pengujian metode susceptibility test mengunakan impragnated paper Fenitrothion 1\% di Kecamatan Mejobo Kabupaten Kudus Tahun 2017 menunjukan bahwa kematian nyamuk uji pada pengulangan I yaitu $96 \%$ sedangkan pada pengulangan II dan III sebanyak 100\%, sehingga rata-rata kematian nyamuk uji dari Kecamatan Mejobo yaitu 98,67\% ditunjukkan pada Tabel 4.

Terjadinya resistensi dipengaruhi beberapa faktor, terutama penggunaan insektisida dalam waktu yang lama yaitu 2-20 tahun dan dosis yang tidak standar (Georghio and Melon, 1983 dalam Yohanes Didik S, 2016, h.40). Hasil uji resistensi terhadap insektisida Fenitrothion 1\% di Kabupaten Kudus rata-rata menunjukkan hasil 99,67\% yang berarti tergolong masih sensitif. Hal tersebut dikarenakan insektisida jenis fenitrothion golongan organofosfat ini belum pernah digunakan dalam pengendalian vektor DBD secara kimia. Dikarenakan susunan kimia yang berbeda dengan insektisida sebelumnya yang telah digunakan, maka Kabupaten Kudus berdasarkan hasil uji resistensi menggunakan metode susceptibility test dengan impragnated paper Fenitrothion 1\% masih rentan/sensitif terhadap insektisida Fenitrothion 1\%.

\section{Kesimpulan}

Status resistensi nyamuk Aedes aegpti pada uji resistensi metode susceptibiitytest menggunakan impragnatedpaperFenitrothion 1\% di Kabupaten Kudus Provinsi Jawa Tengah masih tergolong rentan/sensitif.

\section{Saran}

a.Insektisida Fenitrothion 1\% golongan organofosfat dapat digunakan sebagai solusi alternatif cara pengendalian nyamuk Aedes aegypti secara kimia bagi insektisida lain yang dinyatakan telah resisten b.Perlu adanya pemantauan uji resistensi kembali terhadap insektisida yang digunakan dalam 
pemberantasan nyamuk Aedes aegypti sebagai vektor Demam Berdarah Dengue (DBD).

c.Melakukan rotasi atau pergantian jenis insektisida yang digunakan dalam pengendalian nyamuk Aedes aegypti secara kimia.

\section{Ucapan Terima Kasih}

Penulis mengucapkan terima kasih kepada Bapak Sugiyanto, S.Pd., M.App. Sc.selaku Direktur Politeknik Kesehatan Kemenkes Semarang, Bapak Asep Tata Gunawan, S.K.M., M.Kes.selaku Ketua Jurusan Kesehatan Lingkungan Purwokerto, Bapak Suparmin, S.ST., M.Kes. selaku Ketua Prodi Diploma III Kesehatan Lingkungan Purwokerto, Bapak Dr. Aris Santjaka, S.K.M., M.Kes. selaku Dosen Pembimbing, dan segenap dosen dan karyawan Prodi D-III Kesehatan Lingkungan Purwokerto

Ucapan terima kasih juga disampaikan kepada Bapak Dr. Hari Santoso, S.K.M., M.Epid, M.H.Kes. selaku Kepala BBTKLPYogyakarta yang memperkenankan penulis untuk dilibatkan dalam proses penelitian yang dilakukan oleh pihak BBTKLPP Yogyakarta, Bapak Yohanes Didik Setiawan, S.Si., M.Sc., Ibu Kustiah, S.Si., dan IbuAndiyatu, S.K.M., M.Si. dari Laboratorium Entomologi yang telah membantu dalam proses penelitian dan banyak memberikan saran.

\section{Daftar Pustaka}

Adifian, Hasanuddin Ishak, Ruslah La Ane, Kemampuan Adaptasi Nyamuk Aedes aegypti dan Aedes Alpbopictus dalam Berkembang Biak Berdasarkan Jenis Air, Makassar:UNHAS

Aris Santjaka, 2016, Pendugaan Resistensi Vektor Melalui Analisis Cohort Densitas Nyamuk Pasca Fogging Focus Demam Berdarah, Purwokerto:Politeknik Kemenkes Semarang

, 2016, Zika dalam Perspektif Vektor dan Upaya Pengendaliannya, Purwokerto: Politeknik Kesehatan Semarang Jurusan Kesehatan Lingkungan Purwokerto

Badan Pusat Statistik Kabupaten Kudus, Kependudukan, at

https://kuduskab.bps.go.id/Subjek/view/id/12\#s ubjekViewTab3|accordion-daftar-subjek1, Diakses pada tanggal 20 Juni 2017

Bina Ikawati, Sunaryo,Dyah Widiastuti, 2015, Peta Status Kerentanan Aedes aegypti (Linn.) terhadap Insektisida Cypermethrin dan Malathion di Jawa Tengah, Banjarnegara:P2B2 Banjarnegara

Cahya Edi Prastyo, 2011, Pengaruh Pemanasan dengan Lampu Pijar dalam Berbagai Daya terhadap Perkembangan Pra Dewasa Nyamuk Aedes aegypti di Laboratorium, at http://eprints.undip.ac.id/34828/1/4068.pdf, Diakses pada tanggal 20 Juni 2017

Chasan Sudjain Kusnadi, 2006, Pengendalian Vektor dan Binatang Pengganggu (Vektor Control Manual), Makasar:Poltekkes Kesehatan Lingkungan Makasar

Dani Setiadi, 2016, Deskripsi Mass Blood Survey (MBS) di Kabupaten Purworejo Tahun 2015, Purwokerto: Kementerian Kesehatan Republik Indonesia Politeknik Kesehatan Kemenkes Semarang

Depkes RI, 1994, Petunjuk Teknis Pemberantasan Nyamuk Penular Penyakit Demam Berdarah Dengue, Jakarta : Ditjen PP dan PL

, 2005, Pencegahan dan Pemberantasan Demam Berdarah Dengue di Indonesia, Jakarta : Kementerian Kesehatan RI

, 2001, Pedoman Ekologi dan Aspek Perilaku Vektor. Jakarta : Ditjen PP dan PL

, 2011, Modul Pengendalian Demam Berdarah Dengue, Jakarta:Ditjen PP dan PL

Dinas Kesehatan Kabupaten Kudus, 2015, Profil Dinas Kesehatan Kabupaten Kudus Tahun 2015, Kudus: Dinas Kesehatan Kudus

Dinas Kesehatan Provinsi Jawa Tengah, 2016, Buku Saku Kesehatan Triwulan 2 Tahun 2016, Semarang: Dinas Kesehatan Provinsi Jawa Tengah

Eka Yuniarsih, 2010, Uji Efektivitas Losion Repelen Minyak Mimba (Azadirachta indica A. Juss) terhadap Nyamuk Aedes aegypti, Jakarta: Universitas Islam Negeri (UIN) Syarif Hidayatullah

Elsa Endiyani, 2016, Kohort Densitas Nyamuk pada Fogging Focus di Desa Kedungrandu Kecamatan Patikraja Kabupaten Banyumas Tahun 2015, Purwokerto: Kementerian Kesehatan Republik Indonesia Politeknik Kesehatan Kemenkes Semarang

Firda Yanuar Pradani, Mara Ipa, Rina Marina, Yuneu Yuliasih, Penentuan Status Resistensi Aedes aegypti dengan Metode Susceptibility di Kota Cimahi terhadap Cypermethrin, Ciamis: Loka Litbang P2B2 Ciamis

Genis Ginanjar, 2004, Apa yang Dokter Anda Tidak Katakan tentang Demam Berdarah, : Yogyakarta:B-first

Ginanjar Rahmadani Putri, 2014, Ekslporasi Spesies Larva Nyamuk di Selokan Perumahan Teluk Kecamatan Purwokerto Selatan Kabupaten Banyumas (Studi Kasus Perumahan Teluk) Tahun 2014, Purwokerto: Kementerian Kesehatan Republik Indonesia Politeknik Kesehatan Kemenkes Semarang

Irawan Endy Pratama, 2016, Kohort Evaluasi Nyamuk Dewasa Setelah Pelaksanaan Fogging Focus di 
Desa Sidamulih Kecamatan Rawalo Kabupaten Banyumas Tahun 2016, Purwokerto: Kementerian Kesehatan Republik Indonesia Politeknik Kesehatan Kemenkes Semarang

Isvasta Ekha, 1989, Dilema Pestisida Tragedi Revolusi Hijau, Yogyakarta: Penerbit Kanisius

Kabul Bayu Saputra, 2014, Ekslporasi Spesies Nyamuk di Selokan Kecamatan Purwokerto Selatan Kabupaten Banyumas (Studi Kasus pada Perumahan Teluk) Tahun 2014, Purwokerto: Kementerian Kesehatan Republik Indonesia Politeknik Kesehatan Kemenkes Semarang

Kementerian Kesehatan Republik Indonesia, 2012, Pedoman Penggunaan Insektisida (Pestisida) dalam Pengendalian Vektor, Jakarta: Direktorat Jenderal Pengendalian Penyakit dan Penyehatan Lingkungan

, 2013, Pedoman Pengendalian Demam Berdarah Dengue di Indoesia, Jakarta: Kemenkes RI

Lidia, Kartini dan Elizabeth Widianingrum. 2008. Deteksi Dini Resistensi Nyamuk Aedes albopictus Terhadap Insektisida Organofosfat di Daerah Endemis Demam Berdarah Dengue di Pali (Sulawesi Tengah)

Nadesul H, 2007, Cara Mudah Mengalahkan Demam Berdarah, Jakarta: Melton Putra Offset

Peraturan Menteri Kesehatan, 2010, Jenis Penyakit Menular Tertentu yang Dapat Menimbulkan Wabah dan Upaya Penanggulangan, Jakarta : Permenkes

Peraturan Menteri Kesehatan Republik Indonesia Nomor 1501/MENKES/PER/IX/2010 tentang Jenis Penyakit Menular yang dapat Menimbulkan Wabah dan Upaya Penanggulangan

Peraturan Menteri Kesehatan Republik Indonesia Nomor : 374/MENKES/ PER/III/2010 Tentang Pengendalian Vektor

Rosita Nurdamayanti, 2016, Evaluasi Program Penyemprotan Rumah di Daerah Endemis Malaria Kabupaten Purworejo Tahun 2016, Purwokerto: Kementerian Kesehatan Republik Indonesia Politeknik Kesehatan Kemenkes Semarang

Soegeng Soegijanto, 2006, Demam Berdarah Dengue, cetakan kedua, edisi kedua, Surabaya:Airlangga University Press

Sunaryo, Puji Astuti, Dyah Widiastuti, 2015, Gambaran Pemakaian Insektisida di Daerah Endemis
DBD Kabupaten Grobogan Tahun 2013, Banjarnegara: Balai Litbang Pengendalian Penyakit Bersumber Binatang Banjarnegara

Sunaryo, Bina Ekawati, Rahmawati, Dyah Widiastuti, 2014, Status Resistensi Vektor Demam Berdarah Dengue (Aedes aegypti) Terhadap Malathion 0,8\% dan Permethrin 0,25\% di Provinsi Jawa Tengah, Banjarnegara: Balai Litbang Pengendalian Penyakit Bersumber Binatang Banjarnegara

Tri Cahyono, 2014, Pedoman Penulisan Proposal Penelitian dan Karya Tulis Ilmiah/Skripsi, edisi revisi ketiga, Purwokerto:Politeknik Kesehatan Kementerian Kesehatan RI, Kesehatan Lingkungan

Tri Wijayanti, 2008, Vektor dan Reservoir,Banjarnegara : Loka Litbang P2B2 Banjarnegara

Undang-undang Republik Indonesia, 1984, Wabah Penyakit Menular, Jakarta : Undang-undang Republik Indonesia

Undang-undang Republik Indonesia Nomor 4 Tahun 1984 tentang Wabah Penyakit Menular

Undang-undang Republik Indonesia Nomor 36 Tahun 2009 tentang Kesehatan

Widiarti, Bambang Heriyanto, Damar Tri Boewono, Umi Widyastuti Mujiono, Lasmiati, Yuliadi, 2011, Peta Resistensi Vektor Demam Berdarah Dengue Aedes aegypti Terhadap Insektisida Kelompok Organofosfat, Karbamat, dan Pyrethroid di Propinsi Jawa Tengah dan Daerah Istimewa Yogyakarta, Salatiga: Balai Besar Penelitian dan Pengembangan Vektor dan Reservoir Penyakit Salatiga

Wikipedia, “Insektisida”. https://id.wikipedia.org/wiki/Insektisida, Diakses pada tanggal 14 November 2016

Yohanes Didik Setiawan, 2016, Status Kerentanan Nyamuk Aedes aegypti terhadap Insektisida di Kabupaten Jepara Propinsi Jawa Tengah, Yogyakarta : Balai Besar Teknik Kesehatan Lingkungan dan Pengendalian Penyakit 